\title{
Permanent preservation, coverage area and use of the land in the hydrographic basin of the Almas River, microregion de Ceres, Goiás, Brazil
}

\author{
Áreas de preservação permanente, cobertura e uso \\ da terra da bacia hidrográfica do rio das Almas, \\ microrregião de Ceres, Goiás, Brasil
}

Maria Gonçalves da Silva Barbalho ${ }^{a}$ José Luiz de Andrade Franco ${ }^{b}$ Antonio Cezar Leal ${ }^{c}$ Josana de Castro Peixoto ${ }^{d}$

${ }^{a}$ Doutora em Ciências Ambientais pela Universidade Federal de Goiás e Professora Titular do Centro Universitário de Anápolis, Anápolis, GO, Brasil. E-mail: mariabarbalho2505@gmail.com

bProfessor Associado do Departamento de História, do Programa de Pós-Graduação em História, do Programa de Pós-Graduação em Desenvolvimento Sustentável, Universidade de Brasília, Brasília, DF,

Brasil.

E-mail: jldafranco@gmail.com

'Professor Assistente na Universidade Estadual Paulista Júlio de Mesquita Filho, Unesp, Preseidente Prudente, SP, Brasil. E-mail: cezar.leal@unesp.br

${ }^{d}$ Doutora em Biologia pela Universidade Federal de Goiás e Professora titular do Centro Universitário de Anápolis e da Universidade Estadual de Goiás (UEG), Anápolis, GO, Brasil. E-mail: josana.peixoto@gmail.com doi:10.18472/SustDeb.v10n3.2019.24751

Received: 21/05/2019 


\begin{abstract}
The aim of this study was to map the Permanent Preservation Areas (PPAs), as well as land cover and land use in the Almas River basin in Goiás, Brazil, based on geoprocessing. The results showed the remnants of the original vegetation are limited to fragments and occupy $32.52 \%$ of the area. Grassland is the dominant use, which is distributed throughout the area. Sugar cane and grains secondarily occupy other areas of the river basin. The mapped permanent preservation areas occupy an area of $1,182.22 \mathrm{~km} 2$, representing only $11.53 \%$ of the basins total area. The PPAs located on slopes with a 45은 had a smaller area mapped and they were less affected by the use, whereas those of PPAs located in the springs and watercourses with larger area. Land use, disregarding APP areas, can endanger vital areas that, if degraded, represent damage to water resources.
\end{abstract}

Keywords: Mapping, Classification based on objects, Environmental management, Sustainability.

\title{
RESUMO
}

Este trabalho teve como finalidade elaborar o mapeamento das áreas de preservação permanente (APPs), e da cobertura e uso da terra na bacia hidrográfica do rio das Almas em Goiás, Brasil, com base no geoprocessamento. Os resultados revelaram que os remanescentes de vegetação original limitam-se a fragmentos e ocupam $37 \%$ da área. A pastagem é o uso dominante, o qual se distribui por toda área. A cultura da cana de açúcar e grãos ocupam, secundariamente, outras áreas da bacia hidrográfica. As áreas de preservação permanente mapeadas ocupam uma superfície de 1.182,22 km2 representando apenas $11,53 \%$ da área total da bacia. As APPs situadas em encostas com inclinação de 45 apresentaram menor área mapeada e foram menos afetadas pelo uso, enquanto que as de APPS situadas nas nascentes e cursos d'água, com maior área, foram as mais afetadas pelo uso indevido da terra. O uso da terra, desconsiderando as áreas de APPs, pode colocar em risco áreas importantes que, se degradadas, representam danos aos recursos hídricos.

Palavras-Chave: Mapeamento. Classificação baseada em objetos. Gestão ambiental. Sustentabilidade.

\section{INTRODUCTION}

The combination of political, economic and social processes has caused major changes in the landscapes in the Cerrado's morphoclimatic domains, as shown by land cover and use mapping and its monitoring from orbital images (SANO et al., 2007; STRASSBURG et al, 2017; BRASIL, 2015; TREVISAN \& MOSQUINI, 2015).

Morphoclimatic and phytogeographic domains and / or landscape domain is a geographic classification system based on geomorphological, climatic and botanical criteria that create complex contrasts responsible for composing landscape spatial arrangements (AB'SABER, 1997).

The Cerrado Domain is recognized as the richest savannah in the world, housing a flora of over 12,000 species, of which $40 \%$ are endemic and rich with birds, reptiles, amphibians and fish. Over the past 35 years, due to the expansion of the agricultural frontier, more than 200 million hectares of natural vegetation has been converted into pasture and annual crop areas (KLINK and MACHADO, 2005; BRANNSTROM et al., 2008; AB'SABER, 1983; BARRETO, BRAZ AND FRANÇA, 2016).

Despite boosting the economy, the expansion of the agricultural frontier has produced several imbalances that culminated in environmental degradation. Intensive and indiscriminate deforestation, which has led to reduced biodiversity, erosion, siltation, soil and water contamination (Cunha, 1994; Novaes PintO, 1993; FERREIRA, et al., 2008; Castro, 2005; DUTRA E SILVA, et. al., 2018).

In Goiás state the panorama was no different. The Cerrado covered $97 \%$ of the State area (MMA, 2010), but in 2011 the coverage percentage was only 37\% (BARBALHO and ALVES, 2013). Natural phytophysiognomies have been replaced by pastures, grain crops and in recent years by sugarcane (BARBALHO; SILVA and CASTRO, 2015). 
In the watershed of the Rio das Almas, research area, the effects of this process can be seen in the landscape, especially in areas of water and ecological relevance, such as riparian vegetation occurrence areas (FERREIRA, 2016).

Riparian ecosystems develop in areas resulting from conditions of permanent or periodic excess moisture. The soils are hydrolyzed or acidic and heterogeneous in terms of texture, structure and fertility. The saturated zone is located near the surface with reduced effective depth, due to the dependence of the groundwater depth and the conditions of air temperature and humidity (EMBRAPA, 2013; RIZZI, 2011).

Riparian areas were protected by legal mechanisms established by Federal Law no. 4,771 of September 1965, which created the Brazilian Forest Code. The riparian areas were called permanent preservation areas (PPAs), with the environmental function of preserving water resources and associated landscapes, whether or not covered by native vegetation. In 2012, an update of the Brazilian Forest Code established by Federal Law no. 12,651 of 25 May 2012 and maintained the protection and function of the PPAs, although in some cases it reduced the area to be recovered in case of native vegetation suppression.

Sparovek (2012); Brasil (2012); Santos et al. (2017) draw attention to the fact that PPAs have the function of preserving naturally fragile areas such as springs, surrounding watercourses, hilltops, slopes, valley bottoms and slopes, as well as contributing to the conservation of biodiversity. PPAs act as ecological corridors, enabling connectivity between habitat remnants - which alone would not support viable populations of many animal and plant species - and facilitate migratory and genetic flows (MARTINS et al., 1998; METZGER, 2010; MOMOLI , 2011).

Identifying PPAs is one of the first steps to their effective protection. However, one of the problems found for the delimitation of PPAs is the lack of hydrographic data and adequate land cover and land use (RIBEIRO et al. 2010; SPAROVECK et al., 2011).

Given the above, the objective of this study was to delimit the permanent preservation areas (APPs) and prepare the mapping of land cover and use of the watershed of the river Almas, in the Ceres microregion, Goiás state, Brazil. The 1 / 25,000 and 1 / 50,000 scales, respectively, were used from Sentinel satellite images provided by the United States Geological Survey (U.S.G.S.).

\section{MATERIALS AND METHODS}

This research is part of an academic cooperation project and involves a multidisciplinary team composed of researchers from three institutions, namely: Universidade Estadual Paulista - UNESP (Campus Presidente Prudente), Centro Universitário de Anápolis - UniEVANGÉLICA, Universidade de Brasília - UnB. The watershed of the Rio das Almas lies between the geographical coordinates 170 52 '53 "south latitude and 51은 42' 52" west longitude, in the Ceres microregion, Goiás state, Brazil, and has an area of approximately 10,246 km2 (Figure 1), spread over territories of 21 Goiás municipalities, with emphasis on Goianésia, Ceres and Barro Alto. The hydrographic network belongs to the Tocantins river basin, with the main tributaries being the Sucuri, Uru and Verde rivers. The source of the Rio das Almas is located in the Serra dos Pirineus State Park, with an approximate altitude of $1,200 \mathrm{~m}$ and its mouth in the Serra da Mesa lake with an attitude of $450 \mathrm{~m}$. 


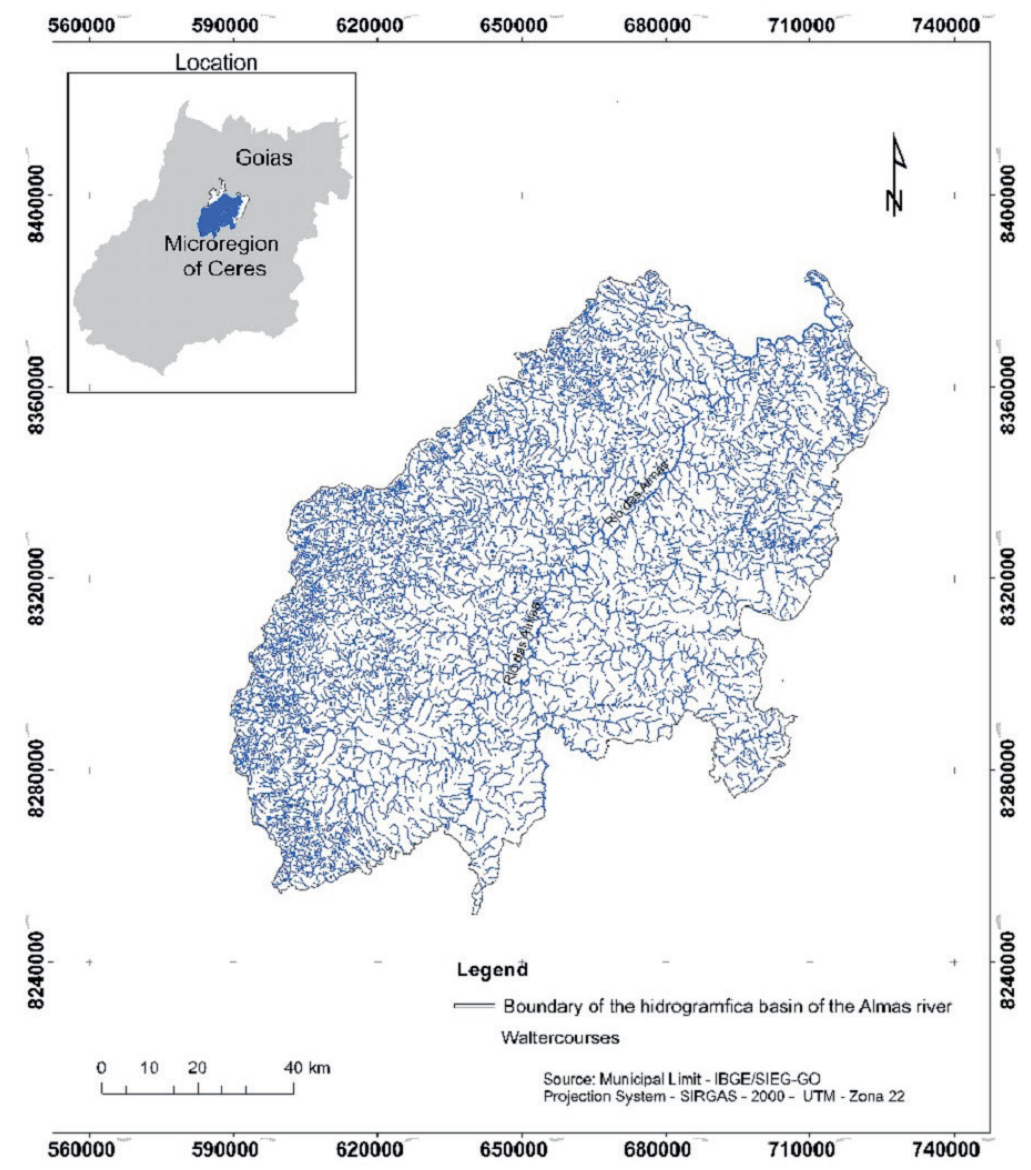

Figure 1 | Location Map of the Rio das Almas watershed, Ceres microregion (GO). Source: the author.

The region received a large migratory flow from the 1940s, motivated by the policies of demographic and agrarian occupation promoted by the March to the West (DUTRA E SILVA, 2017; DUTRA E SILVA \& BELL, 2018). The studies developed and the literature review on the watershed of the Rio das Almas, Ceres microregion (GO), showed that the region has a population of about 231,230 inhabitants and a demographic density of 17.44 inhab./km2. The area occupied by the municipalities is $13,253.36 \mathrm{~km} 2$.

\subsection{GEOPROCESSING}

To prepare the Land Coverage and Use Map on the approximate 1: 50,000 scale (semi-detail), Sentinel satellite imagery provided by the United States Geological Survey (USGS) from 2016. Classification through segmentation (BLASCHKE AND KUX, 2005; BLASCKE et al., 2014) based on the region growth algorithm, which labels each "pixel" as a distinct region until every image is segmented, was employed. Similarity threshold and pixel area were set after testing, respectively at 5 and 10.

To classify the regions formed in the segmentation process, the Battacharya algorithm was used, which requires user interaction to identify the regions. Classification errors were corrected in vector editing and visual interpretation. The caption and land use mapping legend has been adapted from the IBGE Technical Land Use Manual (2013). For the remnants of the Cerrado, phytophysiognomic formations were adopted, according to Ribeiro and Valter (1998).

Two field campaigns were carried out to validate the land cover and land use map, mainly to identify phytophysiognomies, based on road maps that covered part of the study area, by representativeness. 
With the GPS (Global Positioning System) were recorded in the field, the points that allowed the mapping corrections. In addition, land uses and different phytophysiognomies were photographed for illustration of cover patterns.

For the elaboration of the drainage network map, RapidEye images were used, in which the drainage was digitalized, in a 1: 25,000 scale (on the computer screen).

To generate APP (riparian vegetation), the Creat Buffers tool, available in ArcGIS, was used to delimit marginal ranges along user-defined watercourses. Table 1 shows the width of the strips for APPs according to the Forest Code, Federal Law No. 12,651 of 2012 (Table 1).

Table 1 | Areas of Permanent Preservation as of Federal Law 12,651 of 2012.

\begin{tabular}{|c|c|}
\hline $\begin{array}{c}\text { Course width } \\
\text { Less than } 10 \mathrm{~m}\end{array}$ & $\begin{array}{c}\text { Permanent Preservation Area } \\
30 \text { metros }\end{array}$ \\
\hline 10 to $50 \mathrm{~m}$ & 50 metros \\
\hline 50 to $200 \mathrm{~m}$ & 100 metros \\
\hline 200 to $600 \mathrm{~m}$ & 200 metros \\
\hline Over than $600 \mathrm{~m}$ & 500 metros \\
\hline
\end{tabular}

Source: the author.

To delimit the slope APPs, the slope gradient matrix map was prepared in ArcGIS 10.1 using the "Slope" tool. Subsequently, the slope map was reclassified in order to delimit only the APPs above 45․

The 2012 Forest Code established as hill tops with a minimum height of $100 \mathrm{~m}$ and an average slope of 250. The APPs shall cover the set of hills or peaks whose summits are separated by a distance of less than 500 meters, delimited from the level curve corresponding to two thirds of the height from the base of the lowest set hill or mountain. To delimit the hilltops, the methodology of Hott et al (2004) was used.

From the data obtained in the previous stages, the tabulation between land cover and land use map of the year 2016 with the APP data was verified to verify the situation of these areas. It is worth mentioning that the cross tabulation process is an important component for statistical data analysis in which the classes of two information planes are compared, determining the distribution of their intersections. The results represent two-dimensional tables (DGI / INPE, 2019).

\section{RESULTS E DISCUSSION}

For the mapping of land cover and use in the watershed of the Rio das Almas, Ceres microregion (GO), the classification by segmentation was performed, using the statistical method of growth by regions, since the review carried out on mapping of land cover and use from high resolution satellite imagery has shown that object or segment based classification has often been used for mapping agricultural areas because it leads to qualitatively convincing and operational results (BLASCHKE et al., 2014).

The map of land cover and land use of the Rio das Almas watershed in the Ceres microregion of 2016 can be seen in Figure 2. 


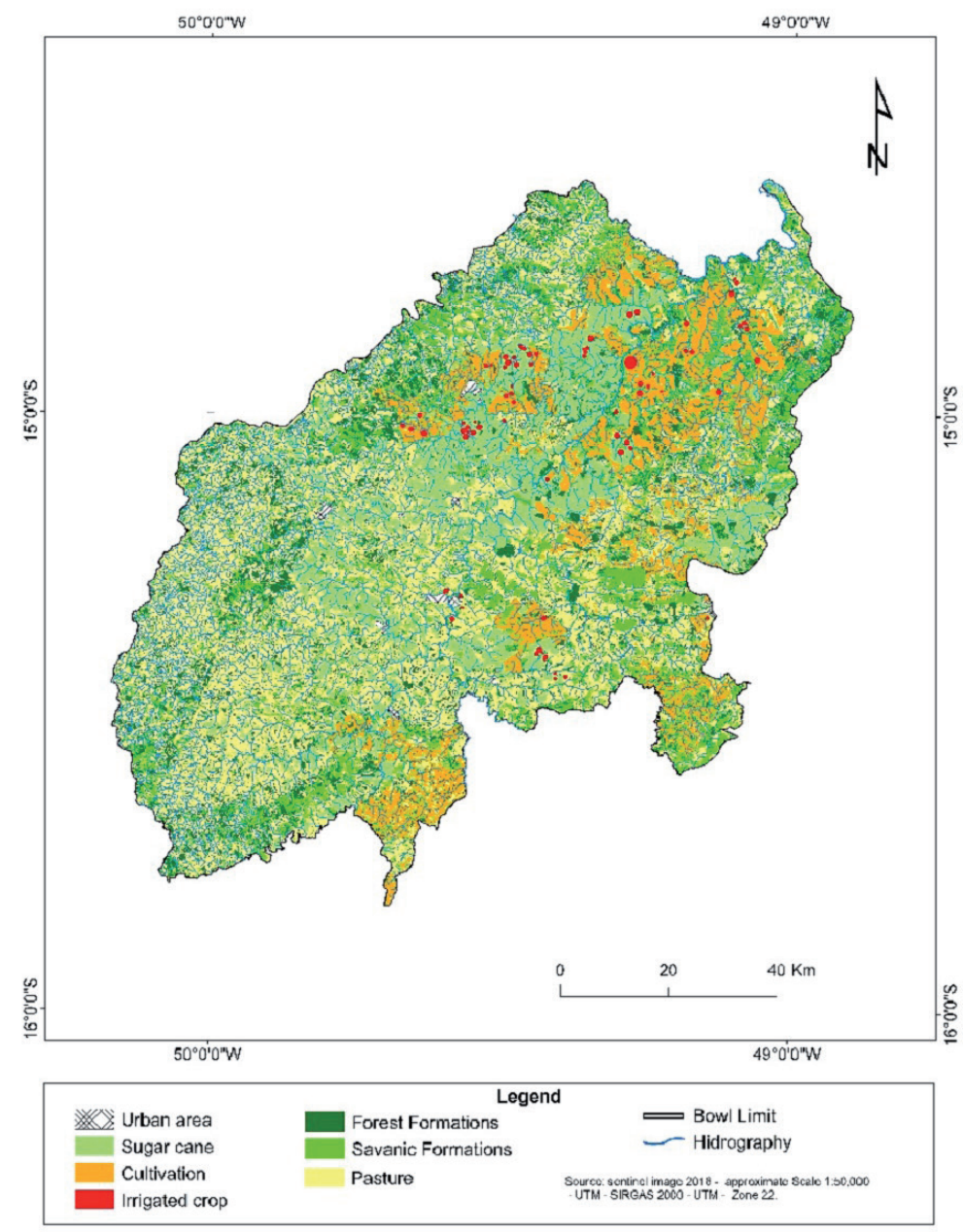

Figure 2 | Coverage and Land Use Map of the Rio das Almas watershed, Ceres microregion (GO), 2016. Source: the author.

Figure 2 shows that the remnants of vegetation of the Rio das Almas watershed are limited to fragments, which occupy $37 \%$ of the area. The largest occur in the northwest, central and northeast portions of the basin. In the southeastern portion, there are few fragments, and smaller, being necessary a detailed study to verify the degree of conservation of these remnants and the possibilities of restoration of these areas. The remainder of the area is being used by agriculture, mainly pasture, which occupies $40.54 \%$, and is distributed throughout the river basin; followed by sugar cane, with $13.12 \%$; and grain cultivation, with just over $7 \%$ of the catchment area (Figure 3 ).

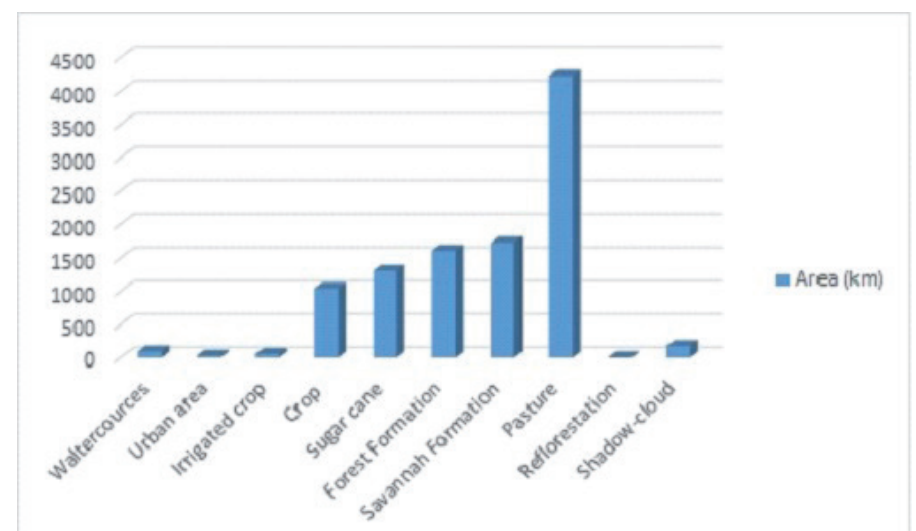

Figure 3 | Area of the Rio das Almas River Basin Coverage and Land Use Classes 2016. Source: the author. 
In the last 20 years, in the Ceres microregion, pasture and grain areas have been replaced by sugarcane (SANTOS et al., 2017). There is also pressure for the conversion of natural vegetation, which still occurs in the region, into sugarcane cultivation areas (SPAROVECK et al., 2008; RIBEIRO, 2010; SILVA AND MIZIARA, 2010; LEAL et al., 2017), Since the microregion is one of the major biofuel producers in the Goiás state.

It should be noted that the expansion of sugarcane cultivation can lead to conflicts over water use, as in some areas there may be a need for rescue irrigation. If these water applications are not well planned, they can have irreversible consequences on water resources (ABADALA and RIBEIRO, 2011).

Grain (soybean, corn) and sugarcane cultivation is predominantly located in the central, northern, eastern and southern portions of the basin. In these areas were mapped 99 central pivot equipment with an average area of 63.06 there, mostly connected to first-order drainage channels, ie, spring areas, which have busbars.

The analysis of the slope map (Figure 4) and the data in Table 2 shows that the area is favorable for agricultural activity, since slopes with up to $12 \%$ (78.50\% of the area) predominate, without topographic restrictions. for mechanization. The strongly undulating mountainous reliefs represent just over $9 \%$ of the area, being restricted to the areas of the mountains.

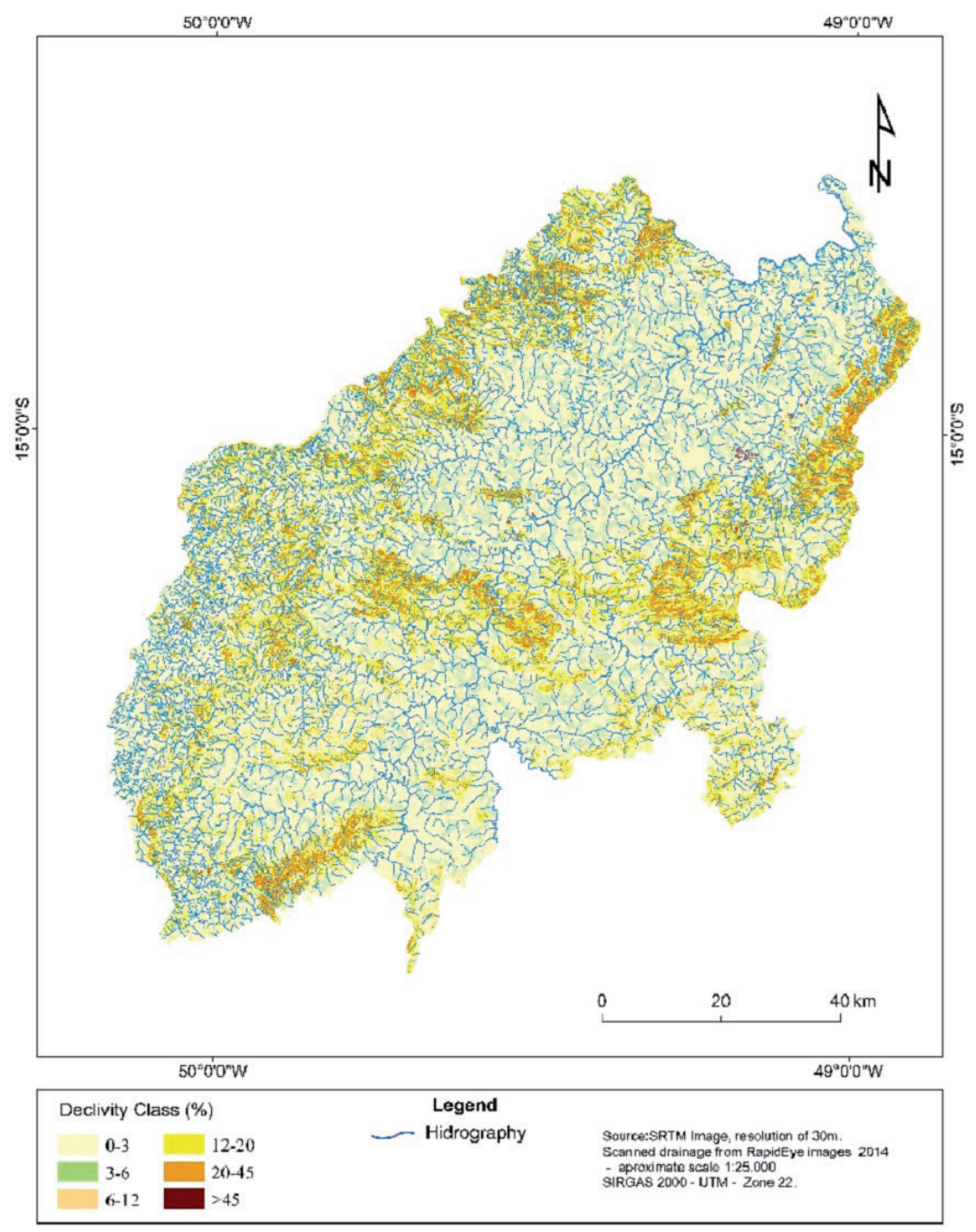

Figure 4 | Declivity Map of the Rio das Almas watershed, Ceres microregion (GO). Source: the author. 
Table 2 | Area of Classes of Slopes of the basin of the river of the Soul, microregion of Ceres (GO).

\begin{tabular}{|c|c|c|c|}
\hline \multirow{2}{*}{ Relief } & \multirow{2}{*}{ Classes (\%) } & \multicolumn{2}{|c|}{ Area } \\
\cline { 2 - 4 } & $0-3$ & $4.932,67$ & 48,14 \\
\hline \multirow{2}{*}{ Plan } & $3-6$ & $1.189,16$ & 11,6 \\
\hline \multirow{2}{*}{ Slightly undular } & $06-12$ & $1.921,59$ & 18,75 \\
\cline { 2 - 4 } & $12-20$ & $1.243,44$ & 12,14 \\
\hline Moderately undular & $20-45$ & 937,49 & 9,15 \\
\hline Strongly undular & $>45$ & 22,05 & 0,22 \\
\hline Hilly & & $10.246,40$ & 100 \\
\hline Total & & & \\
\hline
\end{tabular}

Souce: Adapted from Ramalho and Beek (1995).

The drainage network in the watershed of the Rio das Almas presents the general dendritic pattern, although it presents features that show structural control in some areas. The dendritic pattern develops when the drainage network is over homogeneously resistant rocks, such as granite, sedimentary or metasedimentary rocks with horizontal strata (RICCOMINI et al., 2001; CUNHA and GUERRA, 1995), with tributaries scattered throughout terrain directions. The river of souls is the main drainage and has a length of 468.88 kilometers. (Figure 5 ).

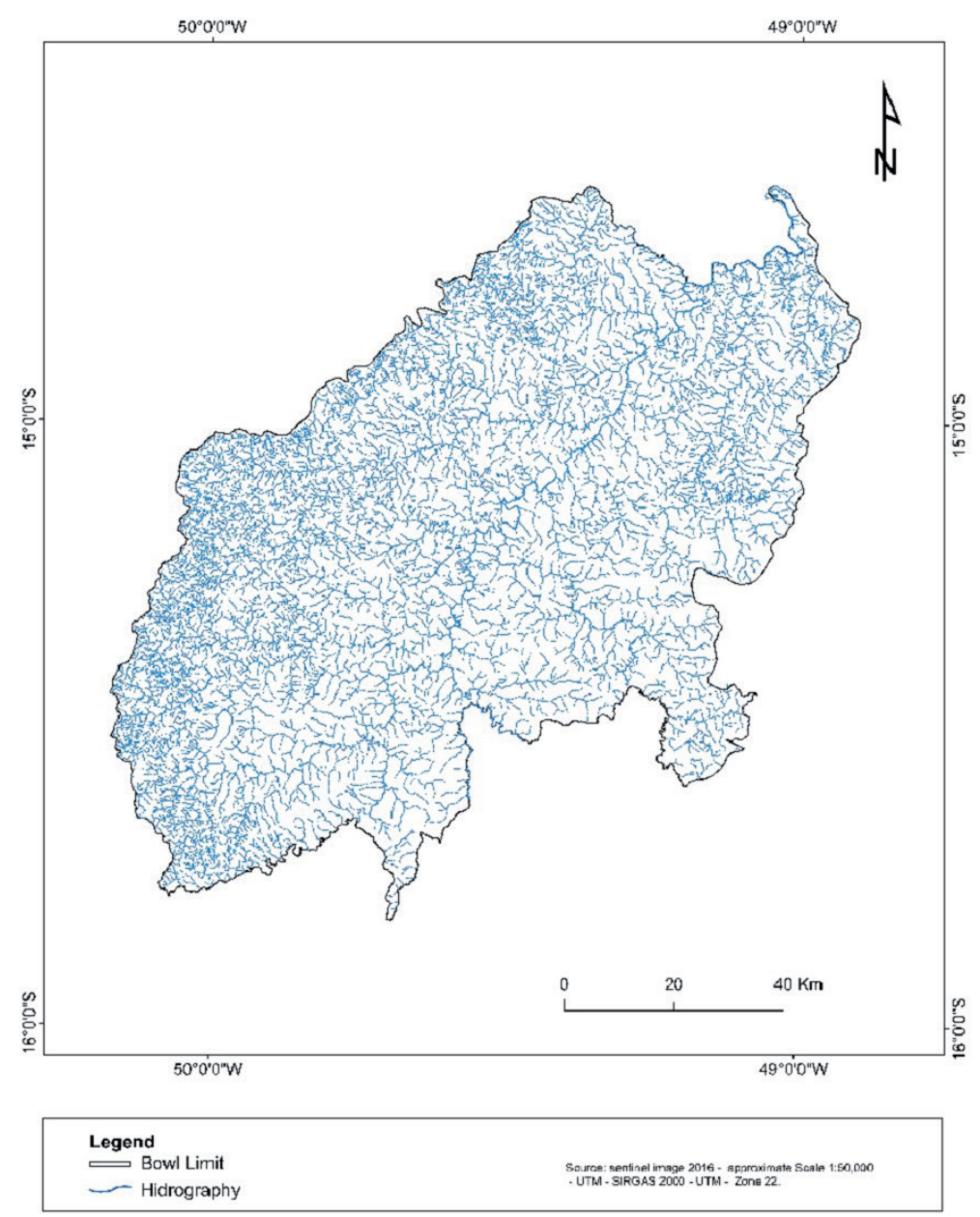

Figure 5 | Drainage map of the das Almas river basin, Ceres microregion (GO). Souce: the author. 
As noted above, the watercourse APPs were delimited and calculated from the drainage network, and the hilltop and slope APPs were delimited from the SRTM images, which can be viewed in Figures 6 and 7. Table 3 presents the quantification of APPs areas.

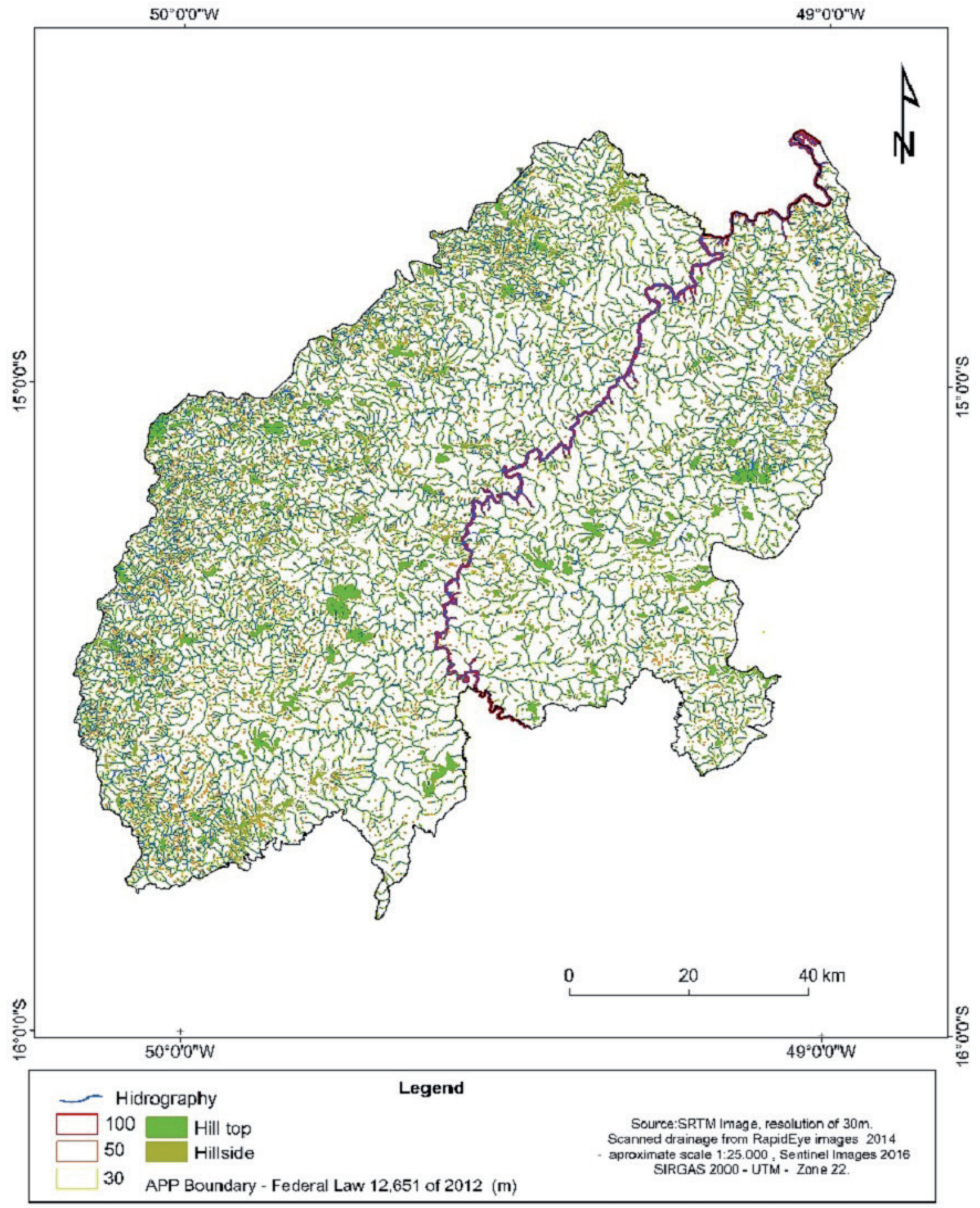

Figure 6 | Map of Permanent Preservation Areas of the Almas river basin, Ceres microregion (GO). Souce: the author 

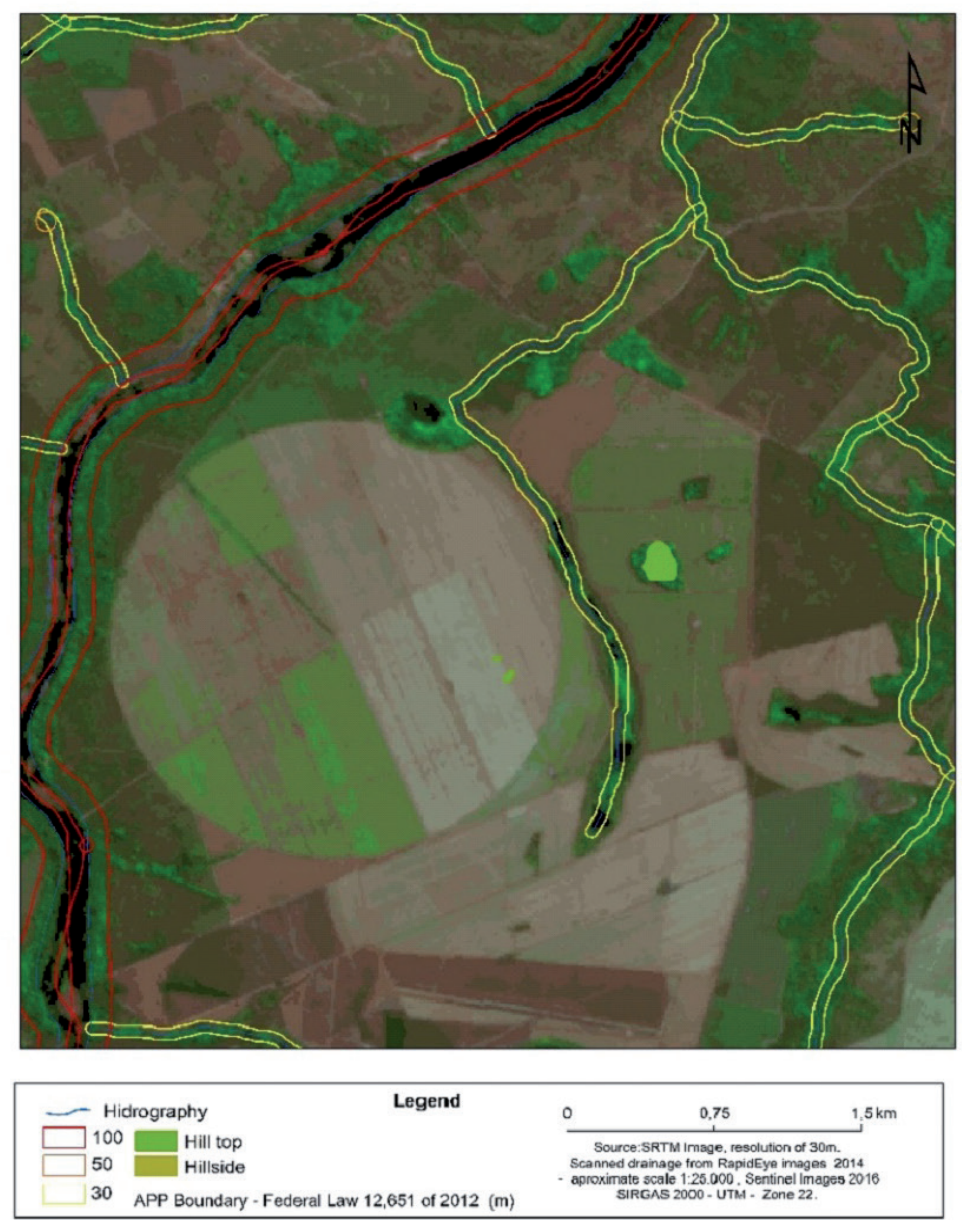

Figure 7 | Image card with the Permanent Preservation Areas of the watershed of the Rio das Almas, Ceres microregion (GO).

Souce: the author.

Table 3 | APP area of the Almas river basin, Ceres microregion (GO).

\begin{tabular}{|c|c|c|c|}
\hline \multirow{2}{*}{ App $(\mathrm{m})$} & \multicolumn{2}{|c|}{ Area } & \multirow{2}{*}{ (\%) in relation to basin area } \\
\cline { 2 - 4 } & $\left(\mathrm{km}^{2}\right)$ & 60,79 & 7,01 \\
\hline 30 & 718,69 & 4,67 & 0,54 \\
\hline 50 Sources & 55,24 & 6,31 & 6,31 \\
\hline 100 & 74,6 & 23,9 & 2,75 \\
\hline Hill top & 282,19 & 4,36 & 0,5 \\
\hline Encosta & 51,5 & 100 & 11,53 \\
\hline Total area de APPs & $1.182,22$ & & \\
\hline Basin Area & $10.246,40$ & & \\
\hline
\end{tabular}

Souce: the author.

From the cross-tabulation between the 2016 land use map and the APP limits of the Rio das Almas basin, we obtained data on the APP areas that are being irregularly used by agriculture and livestock (crop, sugarcane sugar and pastures) as shown in Table 4. 
Table 4 | Cross Tabulation between APP and Land Use of the Almas River Watershed, Ceres Microregion, 2106.

\begin{tabular}{|c|c|c|c|c|c|c|c|}
\hline APPs (m) & Culture & $\begin{array}{c}\text { Irrigated } \\
\text { Culture }\end{array}$ & Urban Area & Sugar cane & Soil Culture & Pasture & Total \\
\hline \multicolumn{8}{|c|}{ Area $\left(\mathrm{km}^{2}\right)$} \\
\hline 30 & 33 & 0,11 & 0,2 & 57,13 & 2,65 & 244,8 & 337,44 \\
\hline $\begin{array}{c}50 \\
\text { Source }\end{array}$ & 2,82 & 0,02 & 0,04 & 3,84 & 0,72 & 23,8 & 31,24 \\
\hline 100 & 0,52 & 0 & 0,06 & 6,61 & 0 & 10,47 & 17,66 \\
\hline Hill To & 14,35 & 0 & 0 & 20,14 & 10,55 & 95,83 & 140,87 \\
\hline Hillside & 0,76 & 0 & 0 & 0,36 & 0,4 & 11,71 & 13,23 \\
\hline Total & 51 & 0,13 & 0,03 & 88,08 & 14,32 & 386,61 & 540,44 \\
\hline
\end{tabular}

Souce: the author.

For the 1,182.22 km2 of APPs delimited by watercourses and tops of hills and slopes, $795.61 \mathrm{~km} 2$ have native vegetation and $386.61 \mathrm{~km} 2$ are in an inadequate situation, that is, they are mainly using livestock $(276,11 \mathrm{~km} 2)$, followed by sugar cane $(88.08 \mathrm{~km} 2)$ and agriculture $(65.32 \mathrm{~km} 2)$. Similar results were found by Ferreira (2015), in a study carried out in the municipality of Carmo do Rio Verde, revealing that pasture occupies the largest area of APPs in the area of the Rio das Almas watershed. Garcia et al. (2015) observed the same situation in the Barra Seca stream watershed (Pedreiras / SP) and Soares et al. (2011) in the São Bartolomeu river basin (MG).

Sousa (2018) analyzed the vegetation cover in the Permanent Preservation Areas - APPs and Legal Reserve - RL of 15 rural properties in the Rio das Almas Hydrographic Region - Foz S. Patrício River / Peixe River - Ceres microregion (GO) and noted that two farms have remaining vegetation far below that established by law; four farms have natural vegetation, but which is below what was established by law; Three properties with an area below four fiscal modules will have to recompose vegetation in accordance with the Code regarding area size; five rural properties have a larger natural vegetation area than established by the RLs legislation.

Mendes and Rosendo (2013) mapped the APPs of springs in the Ribeirão São Lourenço (MG) basin and classified them as preserved, moderately preserved, moderately degraded and very degraded. Results showed that of the 82 springs, $17 \%$ are very degraded, $10 \%$ degraded, $15 \%$ moderately degraded, $13 \%$ moderately preserved and $45 \%$ preserved.

In the order hand, by using the Universal Soil Loss Equation (EUPS),Coutinho (2010) simulated soil losses by water erosion ( $\mathrm{t} / \mathrm{ha} /$ year) in the River Plate (ES) watershed, in GIS environment, and obtained for PPA areas with average soil loss values of $85.43 \mathrm{t} /$ ha / year and maximum values of 3,817.55 t / ha / year. For APP areas with vegetation, the average loss was $27.50 \mathrm{t} / \mathrm{ha} /$ year and the maximum of $996.86 \mathrm{t} / \mathrm{ha} /$ year. These data reveal the importance of vegetation in APPs areas for soil quality and water production in watersheds.

It is important to mention that these areas of APPs that are being occupied in the study area may have consolidated use, that is, Law 12.651 of May 25, 2012, Forest Code, established the concept of consolidated rural area in order to amnesty offenses. committed before July 22, 2008. However, it has been established that on farms, in consolidated rural areas, with up to 1 fiscal module, the restoration of PPA areas should be five meters from the edge of the bed rail. Between 1 and 2 fiscal modules the restoration should be eight meters, and 2-4 fiscal modules should be fifteen meters. For modules larger than 4 the recomposition should be from 20 to 100 meters (Sousa, 2018). And that the deadline for recomposition was not stipulated in the legislation and can be defined by the Environmental Regularization Plan (PRA), (SOUSA, 2018). 


\section{FINAL CONSIDERATIONS}

For inspection, licensing and environmental preservation, mapping of PPAs is essential and in the study area the results revealed that permanent preservation areas occupy a surface of $1,182.22$ $\mathrm{km} 2$ representing only $11.53 \%$ of the total basin area. PPAs located at the tops of 45 -degree slopes had the smallest mapped area and were least affected by use, while PPAs located in the springs and watercourses, with the largest area, were the most affected by misuse. pasture occupying $386.61 \mathrm{~km} 2$, sugar cane $88.08 \mathrm{~km} 2$ and other crops with $65.32 \mathrm{~km} 2$.

The use of geoprocessing made it possible to obtain accurate information on land cover and land use, dimensions and spatial distribution in the landscape.

The use of the high spatial resolution 2016 Sentinel image allowed the mapping of eight land cover and land use classes, with emphasis on the Pasture class, occupying more than $40 \%$ of the total area of the Rio das Almas watershed, microregion. of Ceres, which is $10,246.40 \mathrm{~km} 2$.

\section{ACKNOWLEDGMENTS}

This work was achieved under the PROCAD project New frontiers in the west: relationship between society and nature in the Ceres microregion in Goiás (1940-2013), supported by CAPES - Process 2980/2014".

\section{REFERENCES}

ABDALA, K. de O.; RIBEIRO F. L. Análise dos impactos da competição pelo uso do solo no estado de Goiás durante o período 2000 a 2009 provenientes da expansão do complexo sucroalcooleiro. Rev. Bras. Econ. vol.65 no.4. Rio de Janeiro Out. /Dec. 2011.

AB'SABER, A. N. Bases conceituais e o papel do conhecimento na previsão de impactos. In: AB'SABER, A. N. e PLANTENBERG C. M. (org.) Previsão de Impactos: $O$ estudo do impacto ambiental no leste, oeste e sul. Experiências no Brasil, na Rússia e na Alemanha. 2å ed. 2ạ reimpr. São Paulo: Editora da Universidade de São Paulo, 2006.

AB'SABER, A. N. Domínio dos Cerrados: Uma introdução ao conhecimento. Ver. Serv. Públ. 40 (111) 41 55, 1983.

AB'SABER, A. N. Domínios Morfoclimáticos da América do Sul: primeira aproximação. Geomorfologia. 51:1-21, 1997.

ALMEIDA S. P. Eds. Cerrado: Ambiente e Flora. Planaltina: EMBRAPA - CPAC. 1998. P.89-168.

BARBALHO, M.G.S.; DE CAMPOS, A. B. Vulnerabilidade natural dos solos e águas do estado de Goiás à contaminação por vinhaça utilizada na fertirrigação da cultura de cana-de-açúcar. In: Boletim Goiano de Geografia. Goiânia, v. 30, no 1, jan. /jun. 2010.

BARBALHO, M.G.S.; DUTRA, S.S.; DELLA GUISTINA, C.C. Avaliação Temporal do Perfil da Vegetação da Microrregião de Ceres através do Uso de Métricas de Paisagem. Boletim Goiano de Geografia, v. 35 n.3 set-dez. Goiânia, 2015.

BARRETO, C.G.; BRAZ, V.S.; FRANÇA, F.G.R. Lições para a Biologia da Conservação no Cerrado a partir dos Padrões de Diversidade Genética Populacional do Anfíbio Physalaemus cuvieri. Fronteiras: Journal of Social, Technological and Environmental Science, v.5, n.3, jul.-dez. 2016, p. 101-119. DOI: http://dx.doi.org/10.21664/22388869.2016v5i3.p101-119

BECKER C; OSTERMAN, J; PAHL,M. Automatic quality assentamento of gis data base an object coherence. In: Procedings of the 4th GEOBIA. Rio de Janeiro [s/n], 2012. 
BERGTOLD, J S.; CALDAS, M. M.; Sant'anna, A.C.; G. G.; Rickenbrode, V. Indirect land use change from ethanol production: the case of sugarcane expansion at the farm level on the Brazilian Cerrado. Journal of Land Use Science Vol. 0. 25th European Biomass Conference and Exhibition, 12-15 June 2017, Stockolm, Sweden.

BLASCHKE T. \& KUX H. Sensoriamento Remoto e SIG Avançados: novos sistemas sensores métodos inovadores. São Paulo: Oficina de Textos, 2005.

BLASCKE, T; HAY, G. J; KELLY, M.; LANG, S.; HOFMANN, P; ADDINK, E; FEITOSA, R. Q; MEER, F. V. WERFF, H. J; COILLIE, F. V; TIEDE, D. Geographic Object-Based Image Analysis - Towards a new paradigman. ISPRS Journal of Photogrammetry and Remote Sensing, v. 87, pp.180-1091, 2014

BRANNSTROM, C.; JEPSON, W.; FILIPPI, A.M.; REDO, D., XU; Z.; GANESH, S. Land change in the Brazilian Savanna (Cerrado), 1986-2002: Comparative analysis and implications for land-use policy. Land Use Policy 25, 579-595, 2008.

BRASIL. Lei no 12.651, de 25 de maio de 2012. Diário Oficial [da] República Federativa do Brasil, Brasília, DF, 28 maio 2012.

CARDOSO, M. R. D.; MARCUSO, F.F. N.; BARROS, J.R. Classificação climática de Koppen-Geiger para o Estado de Goiás e o Distrito Federal. ACTA geográfica, v.8 n. 16, pp.44-55, 2014.

jan. /mar. 2014. CIANCIARUSO, M. V.; BATALHA, M. A.; SILVA, I. A. Seasonal variation of a hyperseasonal Cerrado in Emas national park, central Brazil. Flora 200, pp. 345-353, 2005

COUTINHO, L.M. Impacto das áreas de preservação permanente sobre a erosão hídrica na bacia hidrográfica do Rio da Prata, Castelo-ES (Dissertação). Jerônimo Monteiro: Universidade Federal do Espírito Santo, 2010.

COUTINHO, A. C. Segmentação e classificação de imagens LANDSAT-TM para o mapeamento dos usos da terra na região de Campinas, SP. 1997. 150 p. São Paulo. Dissertação de Mestrado. Universidade de São Paulo, 1997.

INSTITUTO DE PESQUISAS ESPACIAIS. http://www.dpi.inpe.br/spring/teoria/aula9.pdf

DUTRA E SILVA, S.; BOAVENTURA, J.K.; PORFÍRIO JÚNIOR, D.E.; SILVA NETO, C.M. A última fronteira agrícola do Brasil: o Matopiba e os desafios de proteção ambiental no Cerrado. Estudios Rurales, vol. 8, № Especial (Octubre), CEAR-UNQ. Buenos Aires; pp. 145-178, 2018.

DUTRA E SILVA, S. No oeste a terra e o céu: a expansão da fronteira agrícola no Brasil Central. Rio de Janeiro: Mauad X, 2018

DUTRA E SILVA, S; BELL, S. Colonização agrária no Brasil Central: fontes inéditas sobre as pesquisas de campo de Henry Bruman em Goiás, na década de 1950. Topoi (Rio J.), Rio de Janeiro, v. 19, n. 37, p. 198-225, jan./abr. 2018.

EMBRAPA. Centro Nacional de Pesquisa de Solo. Sistema Brasileiro de Classificação de Solos: 3a ed. Rio de Janeiro: Embrapa Solos, 2013

FAISSOL, S. O Mato Grosso de Goiás. Rio de Janeiro: IBGE, 1952.

FERREIRA, A. A. de F.; GARRO-TEJERINA, L.F.; BARBALHO, M. G. S.; MAIA, T. C.B. Métricas de paisagem na avaliação da cobertura vegetal em ottobacias do estado de Goiás, Brasil Central. In: Recursos Naturais: indicadores de uso e manejo de biotas, solos e águas no cerrado. 1a ed. Rio de Janeiro: Garamond, 2016.

FERREIRA. A. C. Análise da cobertura e uso da terra no município de Carmo do Rio Verde - GO em 2015: Ocupação das áreas de preservação permanente pela cana de açúcar (Dissertação) Centro Universitário de Anápolis, UniEVANGÉLICA, Anápolis, 2016. 
GARCIA, Y. M.; CAMPOS, S.; SPADOTTO, A.J.; DE CAMPOS, M.; SILVEIRA, G. R. P. Caracterização de conflitos de uso do solo em APP na bacia hidrográfica do córrego Barra Seca (PEDERNEIRAS/SP). Energ. Agric., Botucatu, vol. 30, n.1, p.68-73, janeiro-março, 2015.

GARDIMAN JÚNIOR, B. S.; COUTO, D. R.; SOUZA, F. B. C.; SANTOS JUNIOR, G. N.; SANTOS, A. R. Perda de solo por erosão hídrica em áreas de preservação permanente na microbacia hidrográfico córrego do Horizonte, Alegre, Espírito Santo. Ambiental - Espírito Santo do Pinhal, v. 9, n. 2, p. 0 21-034, maio/jun. 2012.

GUIMARAES, F.de M. S. O Planalto Central e a Mudança da Capital do Brasil. Revista Brasileira de Geografia, n.4 outubro-dezembro de 1949.

INSTITUTO BRASILEIRO DE GEOGRAFIA E ESTATÍSTICA - IBGE. Rio de Janeiro: Mapas de Geologia, Geomorfologia e Solos na escala 1:250.000.

HOTT, M.C; GUIMARÃES, M; MIRANDA, E.E. Método para a determinação automática de áreas de preservação permanente em topos de morros para o Estado de São Paulo, com base em geoprocessamento. Campinas: Embrapa Monitoramento por Satélites; 2004.

INSTITUTO BRASILEIRO DE GEOGRAFIA E ESTATÍSTICA - IBGE. Rio de Janeiro: Censo demográfico 2010.

INSTITUTO BRASILEIRO DE GEOGRAFIA E ESTATÍSTICA - IBGE. Rio de Janeiro: Manual Técnico do Uso da Terra. 3ạ Ed. 2013.

KLINK, C. A.; MACHADO, R. B. Conservation of the Brazilian Cerrado. Conservation Biology, v. 19 (3): 707-713, 2005.

LEAL, A.C.; FERREIRA, R.M.; DUTRA E SILVA, S.; FRANCO, J.L.A.; SAYAGO, D.A.V.; BARBALHO, M.G.S.; TAVARES, G.G.; PEIXOTO, J.C. Novas Fronteiras no Oeste: Relação entre sociedade e natureza na microrregião de Ceres em Goiás (1940-2013). Fronteiras: Journal of Social, Technological and Environmental Science, v.4, n.3, jul.-dez. 2015, p. 219-230.

MARQUES, E. M; RANIERI, V. E. L. Determinantes da decisão de manter áreas protegidas em terras privadas: o caso das reservas legais do estado de São Paulo. Ambiente \& Sociedade, v. 15, n. 1, p. 131-145, 2012

MARTINS, A. K. E.; NETO, A. S.; MARTINS, I. C. M.; BRITES, R. S.; SOARES, V. P. Uso de um sistema de informações geográficas para indicação de corredores ecológicos no município de Viçosa - MG. Revista Árvore, Viçosa Minas Gerais, v. 22, n. 3, p. $373-380,1998$.

MENDES, L. S.; ROSENDO, J. S. Mapeamento da intervenção antrópica em áreas de preservação permanente de nascentes no Cerrado brasileiro. Brazilian Geographical Journal: Geosciences and Humanities research medium. Vol.4(2), 2013.

METZGER, J. P; LEWINSOHN, T.M.; JOLY, C. A.; CASATTI, L.; RODRIGUES, R. R.; MARTINELLI, L. A. Impactos potenciais das alterações propostas para o Código Florestal Brasileiro na biodiversidade e nos serviços ecossistêmicos. Biota Fapesp e ABECO, v.30. p. 1 -13, 2010.

MINISTÉRIO DO MEIO AMBIENTE - MMA. Plano de Ação para Prevenção e Controle do Desmatamento e das Queimadas no Cerrado (2010).

MOMOLI, R. S. Dinâmica da sedimentação em solos sob mata ciliares. 192 p. Tese de doutorado (Doutorado em Agronomia) - Universidade São Paulo, Escola Superior de Agricultura “Luiz de Queiroz", 2011.

PEREIRA JÚNIOR, L. C. O uso da água em Goiás, potencialidade, demanda para irrigação por pivôs centrais e perspectivas. Dissertação (Mestrado) - Universidade Federal de Goiás, Goiânia, 2017. 
RAMALHO FILHO, A.; BEEK, K. J. Sistema de avaliação da aptidão agrícola das terras. 3ạ ed. Rio de Janeiro: EMBRAPA-CNPS, 1995.65p.

RIBEIRO, C. A. A. S.; SOARES, V. P.; MENEZES, S. J. M. C.; LANA, V. M.; LIMA, C. A. Áreas de preservação permanente: espaços (im)possíveis. Ambiência, Guarapuava - Paraná, ISSN 1808 -0251, v. 6. Ed. Especial, p. 93 - $102,2010$.

RIBEIRO, J.F.; WALTER, B. M. T. Fitofisionomias do bioma Cerrado. In: SANO S.M;

RICCOMINI, C.; GIANNINI, P.C.F; MANZINI, F. Rios e processos aluviais. In: TEIXEIRA, W.; et al. Decifrando a Terra. São Paulo: Oficina de Textos. 2000. 191-214.

RIZZI, N.E. Hidrologia Florestal e Manejo de Bacias Hidrográficas (apostila didática em meio digital) 26 capítulos (4gb) disponível em www.hidrologia.ufpr.br, 2011.

SANO, E. E,; ROSA, R.; BRITO, J.L.S.B.; FERREIRA, L.G. Mapeamento de Cobertura vegetal do Bioma Cerrado: Estratégias e Resultados, Embrapa Cerrados, Planaltina. DF. 2007

SANO, E. E; ROSA, R.; BRITO, J. L. S.; FERREIRA, L. G. Mapeamento semidetalhado do uso da terra do bioma Cerrado. Pesq. Agropec. Bras. Jan 2008, vol.43, no1, p.153-156.

SANTOS, R.; SOARES F. B.; BARBALHO, M. G. S.; PEIXOTO, J.de C.; LEAL, A. C. Áreas de proteção permanente e expansão do agronegócio canavieiro: uma análise da microrregião de Ceres, Estado de Goiás, Brasil. Anais do VIII Simpósio Nacional de Ciência e Meio Ambiente. III Escola e Pós-Graduação SOUCHA, out. 2017.

SILVA, A. A; MIZIARA, F. Avanço da fronteira do setor sucroalcooleiro e expansão da fronteira agrícola em Goiás. Pesquisa Agropecuária Tropical, vol. 41, no 3, jul. /Set, 2011, p. 399-407. Universidade Federal de Goiás, Goiás. Disponível em:< http://www.revistas.ufg.br>.

SOARES, V. P.; MOREIRA, A.de A. M.; RIBEIRO, C. A. A. S.; GLERIANI. J. M.; GRIPP JUNIOR, J. Mapeamento de áreas de preservação permanentes e identificação dos conflitos legais de uso da terra na bacia hidrográfica do ribeirão São Bartolomeu - MG. Revista Árvore, Viçosa-MG, v.35, n.3, p.555-563, 2011.

SOARES-FILHO B.; RAJÃO, R.; MACEDO, M.; CARNEIRO, A.; COSTA, W.; COE, M.; RODRIGUES, H.; ALENCAR. A. Cracking Brazil's forest code. Science 344(6182):363-4. 2014.

SOUSA, K.G.R. Cobertura vegetal, áreas de preservação permanente e reserva legal na região hidrográfica do rio das Almas - Foz do rio S. Patrício/rio do Peixe, microrregião de Ceres (GO). Dissertação (Dissertação em Ciências Ambientais) - PPSTMA, Anápolis, p.68,2018.

SPAROVECK, G.; BARRETO, A. G. O. P.; KLUG, I. L. F; PAPP, L.; LINO, J. A revisão do código florestal brasileiro. Novos Estudos, v.89, p. 111- 135, 2011.

SPAROVECK, G.; BERNDES, G.; KLUG, I. L. F; BARRETO, A. G. O. P. Brazilian agriculture and environmental legislation: status and future challenges. Environmental Science \& Technology, v.44, n. 16, p. 6046- 6053, 2010.

SPAROVEK, G. Caminhos e escolhas na revisão do Código Florestal: quando a compensação compensa? Visão Agrícola, p. 25-28, 2012.

SPAROVEK, G.; BERNDS, G.; BARRETO, A. G; KLUG, I. L. F. The revision of the Brazilian Forest Act: increased deforestation or a historic step towards balancing agricultural development and nature conservation? Environmental Science \& Policy, v. 16, p. 65-72, 2012.

STRASSBURG, B.N.; BROOKS, T.; BARBIERI, R.F.B.; IRIBARREM, A.; CROUZEILLES, R.; LOYOLA, R.; SCARAMUZZA, 
C.A.M.; SCARANO, F.R.; SOARES-FILHO, B.; BALMFORD, A. Moment of truth for the Cerrado Hotspot. Nature Ecology e Evolution1, 99. 2017

TREVISAN, D.P.; MOSQUINI, L.E. Dinâmica de Uso e Cobertura da Terra em Paisagem no Interior do Estado de São Paulo: Subsídios para o planejamento. Fronteiras: Journal of Social, Technological and Environmental Science, v.4, n.3, p. 16-30, jul.-dez. 2015.

WAIBEL, L. Vegetação e Uso da Terra no Planalto Central. Revista Brasileira de Geografia, v.10.n.3 1948. 